\title{
UMA PROPOSTA ANALÍTICA DA IMAGEM DA CELEBRIDADE NA MÍDIA ${ }^{1}$
}

Fernando Andacht ${ }^{2}$

\section{INTRODUÇÃO: DA FAMA VISUAL DESCARTÁVEL À CELEBRIDADE ICÔNICA DURADOURA}

O presente trabalho faz parte de uma pesquisa em curso, sobre novos formatos na mídia, como o reality show globalizado Big Brother, que descrevi como melocrônica da ordem de interação (Andacht 2002, 2003, 2004). O objeto de análise me foi sugerido por um artigo de Ramonet (2001) que considera a repercussão de Loftstory, versão francesa de Big Brother. A construção de "celebridades descartáveis", conforme Ramonet (p. 40), é "uma das chaves do sucesso (que) reside na possibilidade fornecida por Big Brother de assistir à construção de famas - embora muito efêmeras". A rápida mudança televisual dos personagens anônimos desse formato em "celebridades descartáveis" é complementar à noção clássica de celebridade, que se associa às estrelas do cinema norte-americano, mas também a outra classe de fama não fílmica abordada aqui. Trata-se do fenômeno da celebridade icônica, cuja análise permite compreender a repercussão de personagens salientes na história do século $\mathrm{XX}$, como é o caso de Eva Perón e Ernesto Che Guevara, que não pertencem ao universo do espectáculo.

1 Este texto foi produzido com o apoio do $\mathrm{CNPq}$ e faz parte da pesquisa em curso intitulada " $\mathrm{A}$ representação do real na época de sua espetacularização midiática"

2 Professor de Comunicação, PPGCOM/UFRGS, Professor Visitante no Programa em Comunicação e Linguagens, da Universidade Tuiuti do Paraná, Curitiba, Dr. Phil. em Estudos Latino-Americanos, Bergen University, Noruega; Doutor em Comunicação da UFRGS, Porto Alegre. Pesquisador do CNPq. [andacht@superig.com.br] 
Para considerar a dimensão comunicacional icônica e qualitativa de suas imagens públicas é necessário descrever a potente sugestão envolvida numa particular relação de semelhança. A semiótica de Peirce é útil para esse objetivo, porque ela propõe uma taxonomia de três tipos de relação sígnica entre o que é representado e aquilo que o representa, quais sejam, o ícone, $o$ indíce e o símbolo. A divisão tríplice se apóia na análise fenomenológica da experiência, a faneroscopia (CP 1.284): $:^{3}$ qualidade, fato e representação. Essas são as três modalidades de ser e conhecer o mundo, as propriedades universais com as quais analisar qualquer fenômeno, social ou natural.

\section{PASSOS PARA UMA INDAGAÇÃO SOBRE A NATUREZA DA CELEBRIDADE ICÔNICA MODERNA}

Qual é a natureza semiótica do irresistível fenômeno da celebridade? ${ }^{4}$ Para responder à pergunta, a reflexão se volta para duas celebridades contemporâneas que provêm de um lugar pouco conhecido do mundo, uma nação situada na parte mais austral de América Latina. Além de partilhar da nacionalidade e da profissão política - uma forma populista de governo do bem-estar e uma luta revolucionária socialista - há algo mais que esses argentinos célebres compartilham, que podemos explicar através da teoria do ícone de Peirce, o signo da semelhança, que partilha de uma qualidade de seu objeto. Trata-se de uma qualidade inerente aos personagens que converte suas imagens públicas em uma espécie de obra de arte. Conforme à exegese de Ransdell (2002), a reflexão estética de Peirce postula a natureza auto-representativa do signo icônico - um fator distintivo de toda obra de arte. Essa propriedade semiótica faz das duas figuras políticas modernas os personagens de culto que eles são.

A história do cristianismo dos primeiros séculos propõe a noção de "profissionais na auto-definição" para descrever as carreiras dos homens veneráveis (holy men) da época. ${ }^{5}$ Foram pessoas que se esforçavam durante sua quase inumana existência ascética, por adquirir uma fama que era a

3 Cito Peirce com o volume e parágrafo, x.xxx nos Collected Papers. Todas as traduções me pertencem.

4 Entre os trabalhos relevantes cabe citar a re-edição do texto de Braudy (1997, pub. orig. 1986) e, em uma perspectiva semiótica, o artigo de King (1992).

${ }_{5}$ Brown, citado em Braudy 1997, p. 177. 
antítese da pompa e da extravagância do imperador romano. Os dois personagens históricos escolhidos podem ser considerados casos modernos de profissionais na auto-definição. Tudo o que Evita e Che fizeram em suas respectivas carreiras contribuiu à construção de um self admirável através da exibição de sacrifício e de talento, mas também através de sua consagração na mídia dominante de sua época. Com diverso grau de autoconsciência, com a tecnologia da comunicação de massa, eles adquiriram uma identidade de natureza dupla: o corpo material e o corpo icônico. Aludo assim, com certa liberdade, ao estudo clássico de Kantorowicz (1957) sobre a instituição da monarquia medieval, à noção de "natureza dual" do soberano. A condição régia era constituída pela dimensão humana - o corpo natural - e pelo vínculo com o poder celestial, do qual o rei extraía seu poder verdadeiro - $o$ corpo político. A conseqüência era a fé coletiva em uma pessoa pública que era a transfiguração de um ser humano em um ícone admirável de Cristo, o christomimétés. A hipótese é que os dois personagens analisados aqui se transformaram em christomimétéi modernos. Obviamente, sua mudança não foi alcançada "pela Graça” (in officio), como acontecia com o rei medieval, mas pela intervenção da tecnologia da imagem de suas respectivas épocas, que contribuiu a transformá-los em celebridades icônicas.

A presente análise é de natureza semiótica, portanto não considera aspectos psicológicos envolvidos na mudança. Porém, a intencionalidade é relevante para a análise semiótica "na medida em que seja algo inerente à obra de arte mesma, considerada como algo que chega a ser o que é através de um processo" (Ransdell, 2002: 20-1). Em vez da "obra de arte" vou considerar a vida pública dessas figuras, que virou objeto estético de adoração para multidões no mundo inteiro.

Num estudo sobre a relevância do "sonho" (dream) na teoria do ícone de Peirce, Colapietro (1988) leva a sério o componente onírico do significado em geral. Trata-se de uma contribuição à análise do ícone em relação ao símbolo. A função do símbolo inclui uma dimensão icônica, a de transportar um sonho ou imagem, o que é visualizado pelo intérprete como o sentido palpável do signo geral e abstrato. ${ }^{6}$ Aqui são consideradas

6 Eis um exemplo no qual Peirce descreve o significado de um símbolo - uma proposição - em termos icônicos: "É algo evidente que [uma proposição] somente transmite sua significação instigando na mente alguma imagem ou ... uma fotografia composta de imagens" (CP 2.317). 
imagens/ícones tanto as fotografias e as ilustrações de uma história em quadrinhos, quanto as descrições verbais em textos literários sobre os personagens. A meta é descrever o efeito massivo que as duas celebridades exerceram e ainda exercem sobre um auditório de magnitude mundial.

Através de um leque de interpretantes visuais, os efeitos de sentido, quais sejam, pôsteres, camisetas, shows de Broadway e filmes baseados na suas vidas, Evita e o Che continuam gerando um fascínio infindável. A sua é uma audiência enorme que, em grande parte, não tem interesse na política populista argentina da primeira metade do século vinte nem na guerra revolucionária socialista cubana. Em vez disso, o que essas pessoas procuram é uma certa qualidade, 'uma idéia ou um sonho muito peculiar sem nenhum isto aqui ou aquilo lá em particular nele (...) mas esse sonho (eles anseiam) realizá-lo com respeito a um objeto da experiência' (CP 1.341). Eis o mecanismo do desejo humano que, conforme Peirce, é de índole geral. O próprio do desejo despertado pelas duas celebridades globalizadas é que ele envolve multidões de sonhadores. Assim o objeto concreto da experiência que esse imenso auditório persegue é evanescente e misterioso, isto é, a felicidade humana concebida como o ideal estético supremo no âmbito cotidiano. De modo extraordinário, as duas figuras de culto têm contribuído a personificar, a iconizar a qualidade denominada kalós, que é o problema central da ciência normativa estética de Peirce. Trata-se de uma qualidade absoluta que é experimentada "na sua presença imediata (como) kalós' (CP 2.199). A noção grega refere-se a aquilo que é sentido como "perfeitamente adequado", e que conseqüentemente é julgado como o mais admirável. O termo kalós, Peirce adverte, não é sinônimo de belo nem de refinado; ele denota o valor supremo e inquestionável em uma comunidade, p. ex. a verdade para a atividade da ciência.

Porém, não é adotado aqui o ponto de vista do especialista em estética, mas o do público, i.e. a perspectiva da multidão de admiradores e seguidores de Evita e de Che. A celebridade é a amplificação, o desenvolvimento qualitativo do efeito onírico que o símbolo produz quando ele é compreendido. Se o aspecto qualitativo predomina sobre a dimensão geral ou conceptual de um signo, então surge um efeito semiótico de fascinação semelhante ao que acontece quando 'ao contemplar uma 
pintura, há um momento em que perdemos a consciência de que não é a coisa mesma; a distinção entre o real e a cópia some, e é nesse instante um sonho puro - não é nenhuma existência particular, mas também não geral. Nesse momento, contemplamos um ícone' (CP 3. 362). Proponho substituir o termo "pintura" na cita de Peirce por cada signo icônico das duas celebridades, incluindo eles próprios como seu ícone, isto é, seus atos públicos funcionariam como um ícone de sua celebridade. Três elementos convergem para produzir o efeito semiótico icônico envolvido nesse fenômeno sociocultural:

1. uma vocação absorvente de uma vida inteira dedicada à autodefinição, à auto-estilização, que é a vontade, o factor dinâmico e histórico que sustenta a qualidade;

2. uma qualidade inerente ao objeto que é observado e que o distingue como auto-representativo;

3. uma tendência social a contemplá-los como uma encarnação inédita da figura de Cristo, como um christomimétés, no qual consiste 0 efeito de sentido do ícone.

\section{CAMPEÕES MODERNOS EM AUTO-DEFINIÇÃO OU COMO VIRAR UM CHRISTOMIMÉTÉS}

Qual é o processo para se converter em um profissional em "autodefinição" (Braudy (1997)? Como funciona a noção de auto-representação, que caracteriza uma obra de arte, algo interpretado como admirável em si mesmo que transcende qualquer uso prático ou religioso do objeto em alguma época? Qual o vínculo entre a celebridade icônica moderna e a iconicidade encarnada pelo soberano medieval, que era considerado a imagem viva de quem foi ungido pela natureza (Christus), conforme Kantorowicz (1957)?

Através do processo de consagração e de apoteose que representam as pinturas estudadas por Kantorowicz (1957: 46), e as descrições literárias da época, um ser humano era ungido pela graça (christus), e virava uma gemina persona, i.e., 'uma pessoa gêmea.' Um processo semiótico semelhante é produzido hoje pela tecnologia da imagem do tempo das duas celebridades argentinas, e resulta em dois singulares christomimétéi da modernidade. Embora não estejam relacionados a alguma igreja ou fé 
religiosa, a duradoura celebridade alcançada por Eva Perón/Evita (19191952) e Ernesto Guevara/Che (1928-1967) pode ser analisada como a capacidade para reproduzir iconicamente, no século XX, o sonho ou imagem que o rei medieval, considerado ícone de Cristo, produzia na Idade Média. A apoteose produzida pela mídia não depende únicamente da classe de engenharia da imagem a qual temos nos acostumado nas quatro últimas décadas, p. ex. em música, em política ou em esportes. É também "em virtude de sua própria natureza interna" (CP 8.335), enquanto signos icônicos, que Evita e Che se transformaram em aquilo que eles são agora. A transfiguração dos dois argentinos em celebridades icônicas e globais resulta dos seguintes fatores:

1. um intenso e constante trabalho sobre o self e sobre o efeito gerado pela apresentação pública do self em outros;

2. a transformação de sua imagem pública em uma espécie de obra de arte, isto é, em um signo icônico e auto-representativo;

3. a efetivação de sua condição de christomimétés de nosso tempo, isto é, um ícone moderno de Cristo com a ajuda da amplificação tecnológica visual da mídia.

\section{A METAMORFOSE DE UMA ESCURA ATRIZ DE PROVÍNCIA EM ÍCONE CRÍSTICO FEMININO}

Um episódio do romance histórico Santa Evita (Martínez, 1995, $S T E$ ), que narra o destino bizarro do cadáver embalsamado de Evita, depois do golpe de estado militar que, em 1955, derrocou o regime de seu marido, o presidente Perón, ilustra as estratégias com que esses personagens escalaram do anonimato à celebridade, em pouco tempo. $\mathrm{O}$ trabalho sobre $o$ self de Evita e do Che se assemelha às estratégias dos homens veneráveis do século IV a.C. para ultrapassar a glória dos imperadores romanos e opacificar sua pompa. Seu intuito era captar a atenção de seu auditório e orientá-la para o reino espiritual do céu. Previsivelmente, os incessantes esforços de auto-estilização contribuíram a edificar sua própria fama.

Numa cena da narração, assiste-se ao esforço de Evita para iconizar uma rainha ou deusa terrena do povo mais humilde da Argentina, as pessoas 
que ela chamava com orgulho "minhas cabecinhas pretas". ${ }^{7}$ Eva Perón está sozinha em uma sala privada de cinema da residência presidencial absorvida no noticiário fílmico Sucesos Argentinos. De fato, o filme é uma seleção de notícias editadas a seu pedido. A única audiência na pequena sala escurecida "movia seus lábios, enquanto ela repetia as palavras do filme" (STE,216). $\mathrm{Na}$ tela, Evita, a infatigável benfeitora da classe operária, é encenada em seu papel de aguerrida lutadora pelo direito ao voto feminino. ${ }^{8}$ De pronto, algo esquisito é observado pelo projecionista: "a mímica (das mãos de Evita) transfiguravam o sentido das palavras." O técnico descobre um desvio intencional das declarações reais gravadas no filme. O resultado da mudança era o sumiço do próprio objeto de aparente admiração de Evita no discurso filmado ao qual assistia, qual seja, seu marido, J. D. Perón:

Se a Evita da tela dizia 'Eu quero contribuir somente com meu grão de areia para a grande obra que o general Perón está realizando', a Evita da platéia inclinava a cabeça, levava as mãos ao peito, ou as esticava em direção a um auditório invisível com tanta eloqüência que a palavra Perón saía do caminho, e somente ouvia-se o som da palavra Evita. Parecia como se, repassando os discursos do passado, ela ensaiasse, perante o espelho estranho da tela, os do futuro." (MARTÍNEZ, 1995, p. 216).

Essa atitude de Evita é comparável ao processo de "auto-estilização" (Brown, em Braudy 1997:178) dos homens veneráveis da época cristã primitiva. Nenhum esforço era poupado por aqueles homens para definir-se e apresentar-se como ideais em toda ocasião pública, como o nexo vivente com Deus, através de suas vidas extremamente austeras. Seu objetivo manifesto era deslustrar a pompa e o luxo dos imperadores romanos, através de uma vida pública de sacrifícios auto-impostos, incrivelmente ásperos:

7 Em alusão às pessoas estigmatizadas, de tez escura, que viajavam das províncias de Argentina à capital.

8 Foi uma hábil e bem sucedida estratégia usada para acrescentar o eleitorado do marido, Juan Domingo Perón. 
$O$ cerimonial imperial, que atrai a atenção da maioria dos historiadores, era apenas um cintilar intermitente se comparado com o trabalho de uma vida inteira dos verdadeiros profissionais da auto-definição. Em uma procissão em Roma, Constantius II ficou de pé, bem erguido, e abstinha-se, por umas poucas horas, de cuspir; mas Simeon Stylites esteve sem mover seus pés durante noites incontáveis; e Macrius o egípcio não tinha cuspido desde que ele foi batizado (BROWN, em BRAUDY, 1997:177).

Mesmo aquelas pessoas "que se separavam de seus camaradas sem nenhuma ambição de ganhar uma audiência para sua auto-limitação" (Braudy 1997:177) não deixavam de atrair seu público, e é bom lembrar ao respeito que "a história da fama é uma história da natureza mudável do auditório e do performer" (id). A missão do homem santo só podia ser atingida através da presença de um auditório atento e adorador que acompanhasse suas façanhas, quer no deserto, quer nos claustros. Apesar dos esforços sinceros para conduzir uma vida pura de total abnegação, como a elogiada coerência de palavras e ações do revolucionário argentinocubano Che, sua vida de sacrifício estava destinada a se transformar em um ícone de perfeição muito louvada. O ícone do "novo homem" procurou reunir as virtudes utópicas do socialismo à humilde existência cotidiana. A briosa auto-negação levou à adoração de um indivíduo excepcional, o corajoso aventureiro cuja imagem estava destinada a se transformar em inumeráveis lembranças e produtos da cultura pop, desde o fim dos sessenta até hoje. Eis um exemplo da auto-estilização extraído de um manual sobre a vida do Che Guevara apresentada através de uma história em quadrinhos:

Não há nenhuma necessidade de homenagens, mas de trabalho! Eu não me importo uma merda com as homenagens, e se vocês são revolucionários, procurem postos de luta nas fábricas! (SINARY y SCENNA, 1996:127).

Essa biografia em quadrinhos, uma espécie de hagiografia light, mostra o Che falando a um grupo de estudantes que o visitam no Ministério de Indústrias. Os jovens querem the prestar homenagem pelo heróico 
episódio de Praia Girón, na revolução que derrocou o ditador Batista, em janeiro 1959. O Che é representado de costas, vestido com a boina escura; ele fala com energia e gesticula com seu punho fechado, parece possuído por uma cólera moral. Por provir de uma brilhante e atrativa figura, sua renúncia apaixonada a toda honra só podia despertar uma admiração ainda maior. A ironia é que essa reação é justamente o que o Che representado procura apagar. O distintivo da condição de "celebridades da esquerda" é a tentativa de contrabalançar "o engrandecimento do self através do bem coletivo visado” por eles (Rose 1998). Há um efeito paradoxal causado pela negação insistente do que alguém parece causar em outros: "ninguém estaria mais exaltadamente comprometido no culto da celebridade que quem constrói uma fachada aprimorada de bem público como o véu de sua própria necessidade de aclamação" (id.).

Não é relevante para o presente estudo descobrir qual era a verdadeira intenção das duas celebridades em sua vida pública. O fundamental é que Evita e Che partilham da atitude crística do rei feudal e do homem venerável da era cristã primitiva; eles têm uma dedicação total a transmitir a seus auditórios uma singular experiência, a qual é mediada imaginariamente através deles. A experiência transcendeu a limitada circunstância histórica de suas vidas. Fosse uma extrema ambição pessoal, como é sugerido na descrição literária citada sobre Eva Perón, ou a renúncia aos privilégios da confortável existência de classe média para abraçar as asperezas da vida revolucionária, o relevante na análise proposta é a lavor infatigável investida na apresentação do self. ${ }^{9}$ Às estratégias normais para exibir determinada aparência perante os outros, os dois personagens acrescentaram "um poder psíquico extraordinário" (BRAUDY, 1997:176), análogo ao dos homens veneráveis dos primeiros sete séculos da era cristã. Trata-se da competência para produzir imagens de si mesmos que os fazem sobressair. Quem é testemunha de sua existência pública os contempla como ícones de perfeição através da mídia que representa sua imagem.

O caráter não-representativo ou não mimético da arte, afirma Ransdell (2002:13) não é pertinente para a semiótica, porque a arte enquanto signo

9 É uma alusão à obra clássica de Erving Goffman de 1959, The presentation of the self in everyday life. 
é auto-representativa, além do estilo histórico de expressão. Quando algo funciona como obra de arte não é por atrair a atenção do intérprete para certo objeto, mas por exibir as qualidades de sua própria materialidade sígnica, isto é por ser "auto-representativa". A condição estética é alcançada através de um "processo de controle crítico do ponto de vista da produção e da apreciação ou interpretação da obra de arte" (2002:17). Se substituirmos "controle crítico" pela atitude de admiração irrestrita é possível incluir as celebridades icônicas Evita e do Che na análise semiótica da arte. A veneração envolvida não concerne apenas nem principalmente ao representado por esses personagens - populismo e revolução - mas à presença mesma deles. Isso é o que acontece com a função religiosa histórica de objetos hoje considerados artísticos, "porque a experiência deles possui intensidade, atração e presença subjugante que thes fornece um valor extraordinário, que extrapola outras crenças sobre sua função" (Ransdell 2002:12). A "presença subjugante" dessas celebridades icônicas consiste em um efeito estético cuja natureza é inseparável do caráter de obra de arte peculiar que eles têm. Sua fama é um efeito semiótico ou interpretante análogo ao gerado pela contemplação das propriedades qualitativas da arte. A celebridade icônica de Evita e de Che é o efeito de sentido derivado de sua condição de signos viventes da experiência que surge da contemplação pasmada deles, que provém "do sabor ou da cor peculiar da mediação" (CP 1.533).

\section{O PODER ICÔNICO DE EVA PERÓN: ENTRE CINDERELA E PIGMALIÃO}

Como é possível para uma moça humilde e ilegítima de um vilarejo das pampas empoeiradas virar um célebre christomimétés feminino que vai dedicar sua vida a redimir os pobres, durante o governo do fundador do peronismo? A resposta envolve o conto de fadas Cinderela e o mito de Pigmalião. Não apenas o título do romance, mas a capa de Santa Evita é um indício da ascensão da única fillha não legítima da família Duarte à celebridade nacional e internacional. A imagem na capa representa a protagonista com um halo dourado grande que reluz em redor da cabeça de Evita como um sol pessoal. A auréola transpõe os ombros de uma mulher 
loura e magra, na casa dos trinta anos, que veste o sombrio e simples hábito de um frade. Os braços estão cruzados sobre o peito; o esquerdo segura uma espada, e o direito sustém um delicado ramo de flores pequenas.

No presente estudo, o conceito de christomimétés manifesta-se em duas "chaves" ou "enquadramentos" diferentes, conforme a noção analítica de Goffman (1986). Uma chave transforma uma definição básica de interação social em uma derivativa. No caso de Evita, o desenho transforma a representação feminina em outra de santidade, que é devedora de sua exposição pública e política de abnegação em prol dos miseráveis, à imagem e semelhança de Cristo. ${ }^{10} \mathrm{O}$ que mais atrai a atenção na imagem é o halo, que é uma indicação de que o possuidor era "o portador e o executivo de poder perpétuo derivado de Deus (e que) fazia do imperador a encarnação de uma classe de 'protótipo' que, sendo imortal, era sanctus, sem se importar do caráter pessoal, ou inclusive do sexo, do possuidor" (Kantorowicz, 1957:80). No caso de Evita e do Che não é a função régia cumprida, mas alguma qualidade que sua imagem pública possui e que é exibida de modo persuasivo, o que as converte em um venerado "protótipo", com a ajuda da mídia.

Os itens da seguinte lista são os atributos doados a Evita como presentes semióticos pelo povo e pelo regime peronista, enquanto ela agoniza, consumida por um veloz câncer maligno de útero que a leva à morte, aos 33 anos, em 1952. Os "títulos honoríficos" podem ser resumidos em uma figura icônica, a do personificador moderno de Cristo ou christomimétés, eles são interpretantes históricos daquela noção medieval:

Porta-bandeira dos humildes, Nossa Senhora da esperança, Medalha da Ordem do Libertador General San Martín, Líder espiritual e Vice-presidente Honorária da Nação, Mártir do Trabalho, Padroeira da Província de La Pampa, da cidade de La Plata e dos vilarejos de Quilmes, de San Rafael e de Madre de Dios (STE, 20).

${ }^{10}$ Ainda antes de sua morte, houve uma tentativa popular para ter Eva Perón canonizada: 'Entre o mês de maio de1952 - dois meses antes que ela morresse - e julho 1954, o Vaticano recebeu quase quarenta mil cartas de pessoas laicas que atribuíram muitos milagres a Evita, e que exigiam que 0 Papa a canonizasse”. (STE, 66) 
Fundamental para o efeito de christomimétés de Evita foi a história que circulava entre as pessoas humildes de que ela investia cada partícula de sua energia no trabalho extenuante para os pobres, uma ocupação exclusiva que não the deixava tempo nenhum para se ocupar de sua saúde que se deteriorava com rapidez. $\mathrm{O}$ relato foi sustentado pelo fato irrefutável de sua morte prematura aos 33 anos. A seguinte afirmação provém de uma carta aos leitores da publicação governista Justicialismo - o movimento político fundado por Perón e encarnado persuasivamente por Evita. Em uma carta aberta que ela dirige às mulheres do movimento que fundou (“Compañeras"), a metáfora usada para descrever seu trabalho é um ícone de uma vida de sacrifício interminável e também uma estratégia típica da profissional da auto-definição que ela era:

A todos quero dizer que eu estou nas trincheiras, na fronte da batalha, como ontem, e como sempre. Eu disse que minha dívida para com o povo é infinita, e só poderei pagá-la queimando minha vida pela causa de sua felicidade, e tenho como verdadeiro que a vida deve ser queimada somente para um ideal tão grande como aquele de Perón e de meu povo. (“Compañeras” em Mundo Peronista, setembro 15, 1951, 27 - grifos meus, F.A).

Já é hora de descrever a singular reunião dos mitos de Cinderela e de Pigmalião no corpo icônico de Evita. Três depoimentos históricos recolhidos no romance $S T E$ testemunham a transfiguração de alguém cuja apariência era o contrário de memorável, mas que virou uma imagem crística fascinante capaz de vencer o tempo.

O equivalente midiático da apoteose teológico-jurídica do rei feudal, a cerimônia pela qual "o rei vira 'deificado' por um breve lapso em virtude da graça, entanto o Rei celestial é Deus por natureza eternamente" (Kantorowicz 1957:47, grifos no original). O modo no qual a quase desconhecida Eva Duarte devém Evita, uma personificação de Cristo, se relaciona com sua consagração visual ou apoteose. A líder espiritual do peronismo atingiu a celebridade icônica por dois caminhos: o de Cinderela e o de Pigmalão. O primeiro depoimento provém de um experto em 
iconicidade, o maquiador que trabahou nos últimos dois filmes dela. Após comentar como era inútil ao início tentar ocultar sua vulgaridade com pó facial e outros truques cosméticos, narra sua surpresa, quando quatro anos depois, ela tinha virado em uma "deusa": "Suas feições tinham se tornado tão belas que ela exalava um aura de aristocracia e uma delicadeza de um conto de fadas. Fixei-a para saber que milagroso pó cobria seu rostro.. mas não havia nada (...) A beleza crescia dentro dela sem pedir permissão" (STE, 12). A condição de signo auto-representativo de Evita emerge com clareza na testemunha: há uma qualidade inerente a sua imagem que se relaciona com o efeito Cinderela, a transformação misteriosa da jovem anódina em a rainha maravilhosa dos "cabecitas negras".

O seguinte depoimento vem também do âmbito artístico, de uma atriz que deu refúgio a Eva quando, em 1935, ela chegou a Buenos Aires em procura de fama. Após descrever a classe de mulher que nunca atiraria o olhar dos homens na rua, confessa sua surpresa pela extraordinária transformação acontecida: "Naquele tempo ela era nada ou menos do que nada: um doce mastigado; tão magrinha que dava até pena (...) Ela urdiu para si própria uma crisálida de beleza, foi se empolhando rainha” (12). As interrogações que essa testemunha se faz são uma expressão sincera de fé no efeito-Cinderela encarnado pela figura política e mítica de Evita no século XX:

Como ela fez para conseguir tanta desenvoltura e facilidade da palavra? Donde tirou a força para tocar o coração mais magoado das pessoas? Qual sonho terá lhe caído dentro de seus sonhos (...) para transformá-la da noite para o dia nisso que ela foi: uma rainha? (STE, 12)

Nossa última testemunha inclina-se para o mito de Pigmalão para explicar a mudança fantástica de Eva Duarte em Evita; trata-se de seu cabelereiro pessoal. Julio Alcaraz era "o famoso estilista das estrelas da era dourada do cinema argentino" (STE, 79). Julio descreve como tinha visto Eva na sua hora mais triste, quando a reconheceu na imagem desolada de uma jovem quase sem seios que posava nua em alguns cartões postais pornográficos, em uma banca de jornal de uma rodoviária. Por isso, quando 
ela the pediu ajuda para mudar seu alicaído visual, o cabelereiro sentiu piedade, e ele se dispôs a perder "uma hora e meia de sua valiosa manhã, para evitar o ridiculo da personagem que ela representava nesse filme" (STE, 83). Como o faria dez anos depois Perón, o cabelereiro toma para si o papel de criador do ícone maravilhoso, o Pigmalião desse christomimétés feminino: "No fim das contas, Evita foi um produto meu. Eu a fiz" (id.). Após descrever em detalhe as graduais mudanças do penteado de Evita, Julio conclui que nem sequer ela percebeu o processo de radical metamorfose: "Quando ela se deu conta, já era outra. Eu a fiz, ele repetiu, eu a fiz. Com a pobre garotinha que conheci perto de Mar del Plata eu fiz uma deusa. Ela nem se deu conta" (84). O fato dessa operação icônica ter sido feita por um experto em imagens cativantes do cinema pode ser considerado uma recuperação dessa tecnologia de algo que já era seu: o destino fílmico póstumo de Evita era assim previsível, sua carreira política foi, talvez, o maior filme argentino do século XX. Há um breve relato de J. L. Borges, "A trama", no qual o narrador diz que o anônimo protagonista não sabe que ele é assassinado somente para que "uma história se repita", qual seja, a traição de Julio César nas mãos de seu afilhado, Bruto. No caso de Eva Duarte pode-se afirmar que ela ignora que se transforma em celebridade icônica das massas populares só para que Pigmalião e Cinderela possam continuar vivas na imaginação coletiva.

\section{UM AVENTUREIRO ARGENTINO SE TORNA CELEBRIDADE FOTOGRÁFICA GLOBAL}

Eu não sou Cristo ou um filantropo, mãe; eu luto pelas coisas em que acredito, com as armas a meu alcance, e tento deixar o outro no chão em vez de deixar que eles me preguem em uma cruz. (Carta de Ernesto Guevara a sua mãe, em prisão com Fidel Castro, em Cidade do México, julho 15, 1956 , Guevara, 2001.)

Além da sentença da História no que tange à contribuição na revolução mundial, o Che Guevara pertence à categoria de celebridade icônica, ele é um exemplo de um ícone puro na imaginação social. Através 
de seu constante trabalho na auto-definição, o Che se tornou um ícone de Cristo, não só pelos fatos históricos, objetivos, mas por um processo estético semelhante ao que fez de Eva Perón uma presença icônica poderosa de nosso tempo. A presente reflexão se baseia em textos autobiográficos e em imagens da mídia que ilustram a classe de celebridade que fez dos dois argentinos nomes conhecidos no mundo. A atuação pública do Che, sua vida ascética, seus sacrifícios tudo convergia para sua própria pessoa, para seu "corpo natural", o que determinou o funcionamento semiótico desse outro irresistível corpo icônico.

A celebridade do Che se aproxima da condição de homem venerável da era cristã primitiva, conforme a descrição de Braudy (1997: 175). Porém, há um forte individualismo nesse aventureiro que procura lutar contra a opressão no Terceiro Mundo, e globalizar assim a revolução socialista. Os biógrafos descrevem seu gosto pela qualidade épica da luta, mais que pela transformação política que aquela devia gerar. ${ }^{11}$ Ele foi uma atrativa mistura de Dom Quixote e dos coléricos beatniks norte-americanos que agarravam a estrada, nos anos cinqüenta, para opor-se ao sistema, através de modos alternativos de vida, para transformar a existência normal. ${ }^{12}$ Ernesto Guevara atingiu a fama em um tempo breve, e morreu no auge da glória como um eterno lutador à procura da utopia que, na sua terra adotiva, Cuba, já não parecia possível pelo simples fato do estabelecimento de um regime socialista estável.

Que melhor modo de descrever a natureza icônica da celebridade atingida pelo Che que um manual ilustrado de sua vida, a história em quadrinhos Che Guevara para principiantes $(\mathrm{CHE})$ ?. Em apenas duzentas páginas, segue-se a evolução, do nascimento até a morte, dessa figura romântica, talvez o primeiro lutador globalizado, se levarmos em conta a infindável popularidade de sua imagem em camisetas e pôsteres. Mais surpreendente ainda é que a fama continua e cresce depois de que o sonho socialista pelo qual ele lutou transformou-se em uma lembrança no mundo

11 "A fama do Che estava baseada sobretudo na originalidade de sua personalidade" (García Lupo 2000:59).

${ }^{12}$ Em uma carta a sua mãe, Che lhe explica que abrir uma clínica médica em Guatemala "seria a pior traição dos dois "eus" que brigam em mim: o socialista e o viajante (10/05/1954, Guevara 2001) 
ocidental: hoje 'fragmentos verdadeiros' do demolido muro de Berlim se vendem em cartões postais cafonas, junto com peças do uniforme do Exército Vermelho.

A reputação crescente do revolucionário é representada no capítulo “No coração da história.” Na metade superior da página, há uma imagem de três humildes músicos cubanos tocando seus instrumentos e cantando para lhe homenagear: "Afasta-te do caminho/ Senão eu te jogo fora/Porque vem aqui o Che Guevara acabando com o mundo" (CHE, 96). Na parte inferior da página, vemos o herói com sua boina inclinada, enquanto ele tenta arredar um elogio de um jovem negro ${ }^{13}$ : "Os libertadores não existem, meu irmão. Os povos mesmos se libertam”. Se observarmos a página inteira, compreendemos que o guerrilheiro não parece ter muito sucesso na luta contra sua própria celebridade, a qual vai em aumento. Muito antes de ele ter atingido a fase de ícone heróico na cultura popular, sua imagem já tinha se incorporado ao folclore da revolução como um exemplo paradigmático de resistência e de coragem. A modesta apoteose musical do quadrinho é, de fato, o resultado de duas cerimônias precedentes, que o manual apresenta como consagrações do Che. Em ambas se assiste ao signo icônico que, conforme Kantorowicz (1957: 80), é a imagem da sacralidade crística, qual seja, o nimbus perfectionis ou halo. O primeiro episódio faz parte do capítulo "Um sonho de liberdade," lá lemos que o herói "recebe seu segundo batismo, o mais importante, o que lhe dá o nome com o qual ele vai entrar na história e na lenda" ( $C H E, 66)$. Dois camaradas revolucionários que estão no meio do mato de um acampamento rebelde no México, lhe dizem que o nome "Ernesto parece formal demais. Tu és simplesmente 'o ché'. $O$ CHE GUEVARA" (grifos no o original). ${ }^{14}$ Ser batizado é aqui o equivalente ritual de ser ungido, de virar um christus (Kantorowicz 1957: 74).

O segundo ritual acontece durante a luta libertadora em Cuba. No mesmo capítulo, observa-se outro halo em torno do Che, mas, desta vez, o ícone de consagração é tão grande que ocupa quase toda a tira do quadrinho. É o momento quando ele recebe "uma notícia que lhe comove.

13 O jovem negro diz: "Che, você é um libertador, todo mundo fala isso".

${ }^{14} \mathrm{O}$ termo é uma forma muito comum argentina de se dirigir a alguém, uma variante do "tu". 
Che é nomeado comandante” dos rebeldes ( $C H E, 78)$. Vemos uma mão feminina segurando a estrela que será prendida em sua boina e que "o identifica" daqui por diante. A tira da parte inferior mostra apenas a boina do Che luzindo a estrela e sendo agitada no ar; ele celebra uma vitória revolucionária, enquanto "recebe a alegria do povo". Dessa cerimônia à fotografia de uma mulher de cabelos brancos cuja camiseta exibe 0 ícone mais famoso do Che ${ }^{15}$ completa-se um périplo que leva o leitor das imagens do aventureiro novo até o personagem célebre no mundo. Ernesto Che Guevara terminou seus dias como um christomimétés total, apesar, ou melhor, por causa de sua firme rejeição das honras e do reconhecimento de suas salientes características como indivíduo.

Adiferença capital entre o christomimétésrégio medieval e a celebridade icônica aqui analisada é que nem Evita, nem o Che podem ser considerados “a encarnação de uma classe de 'protótipo' que, sendo imortal, era sacro, sem importar seu caráter pessoal ou o sexo do constituinte" (Kantorowicz 1957:80). Pelo contrário, o efeito icônico atingido por ambas celebridades resulta de uma qualidade que possuem enquanto signos públicos, que foi amplificada pelos meios de comunicação (fotografia, rádio, dramaturgia política). Portanto, sua condição icônica não thes é outorgada pela graça associada à incumbência oficial que devem exercer, como acontece com o rei feudal. Sua distinção provém de uma transformação em obra de arte sui generis, em um signo auto-representativo, através do intenso trabalho na auto-definição.

A imagem exaltada do Che quando rejeita a homenagem dos estudantes e os convoca a lutar nas fábricas pela revolução $(C H E, 127)$ é um exemplo do efeito paradoxal que Rose (1998) julga fundamental para definir a celebridade como "alguém que é muito próximo mas que também encena algo semelhante a um ato de sumiço mágico”. O que o manual ilustrado apresenta como uma resposta "exemplar" do Che a seus admiradores é o contrário do temível culto da personalidade típico dos ditadores. Contudo, quando tal recusa provém de um signo icônico vivente

${ }^{15}$ Se trata da fotografia de Alberto Korda que ele pegou quase por acaso, em 1960 em La Havana. A imagem da mulher inclui um balão com a clássica asserção revolucionária "iHasta la victoria, siempre!" e fecha o manual. 
como o Che, ela gera o efeito inverso. Paradoxalmente, "o reclamo antiperformativo" (Rose, 1998) do Che torna-se mais uma contribuição à transformação dele em um neo-christomimétés, a celebridade icônica encarnada pelo revolucionário. Cabe ligar essa recusa à condição de celebridade e a um relato anônimo das circunstâncias que levaram à criação do "retrato mais famoso do mundo": ${ }^{16}$

Foi quando ele tinha um encargo para a revista Revolución em 1960 que o Sr. Korda tirou a famosa foto do Sr. Guevara em um ato de protesto contra-revolucionário (...) era um dia úmido e frio. (...) com sua máquina Leica garimpava as figuras no palco, quando o rosto do Sr. Guevara pulou na objetiva. O olhar nos olhos do Che lhe surpreendeu tanto que por instinto recuou e acionou a câmera na hora. Parece haver um mistério naqueles olhos, mas na realidade é apenas raiva pelas mortes do dia anterior, e a compaixão por suas famílias. (grifos meus, F.A.)

Sem levar em conta a veracidade do relato, proponho conceber o episódio narrado como a culminação de uma paixão entre a tecnologia fotográfica e a iconicidade do signo Che Guevara - a aparência do homem que tentou encarnar o homem novo da revolução. Desse encontro, surgiu o corpo icônico que eclipsou o corpo natural, que ficou atrás como uma casca vazia, isto é, as propriedades não relevantes do objeto material desse ícone. Refiro-me aos motivos aparentes aludidos na narração, que tentam explicar a expressão facial do Che representada na foto, o dia 5 de março de 1960. Tais razões são tão irrelevantes como o material de sua boina. Em um estudo sobre "as molduras das imagens", Goffman (1985:13) descreve uma classe das fotografias públicas que denomina "flagradas (caught) ou cândidas; elas representam modelos que não foram dispostos para tal serviço... para servir como algo a ser fotografado nessa ocasião." Tudo faz pensar que a fotografia que Korda tirou do Che corresponde ao tipo de imagem "flagrada ou cândida" descrita por Goffman:

${ }^{16}$ Assim descreve um internauta a fotografia do Che feita por Alberto Korda em http://www. photographie.com. Sobre o efeito de construção nacional desses ícones, ver Andacht 2002a. 
Do número infinito de cenas que os fotógrafos poderiam apanhar, eles conseguem (e esforçam-se) por obter apenas um número pequeno, e essas tendem a serem aquelas cujo conteúdo não gera dúvida alguma de que as imagens só poderiam ter sido apanhadas. Assim uma imagem apanhada resulta ser uma que é obviamente apanhada (Goffman, 1985:13).

Rose (1998) define uma celebridade como alguém que está sempre prestes a sumir. Do ponto de vista semiótico, trata-se de alguém que, enquanto celebridade, cria 0 efeito de uma obra de arte, qual seja, "uma presença subjugante que lhe confere um valor extraordinário" (Ransdell (2002:12). À definição de Rose acrescento que a celebridade icônica é alguém que transforma qualquer imagem de si em uma imagem que invalida a oposição entre retratos fotográficos posados e apanhados. Quer planejada quer apanhada pela câmara de Korda, a célebre imagem em preto e branco do Che exibe um jovem revolucionário com boina, escassa barba, cabelo comprido, e aparência severa que chegou a encarnar um sonho obstinado para grande parte da humanidade. Esse sonho tornou-se muito mais influente que os elementos indiciais associados originalmente à imagem, p. ex. os motivos políticos da cerimônia organizada pelo regime de Castro naquela data. A transfiguração dos componentes indiciais e simbólicos ${ }^{17}$ do acontecimento em uma experiência de natureza icônica-estética, constitui o aspecto específico da celebridade icônica. A mudança resulta de um trabalho constante na auto-definição, e da amplificação produzida pela mídia disponível.

O avatar latino-americano de São Francisco de Assis era um jovem da província que renunciou as vantagens da origem burguesa ilustrada, para vestir os farrapos de um uniforme do exército irregular cubano. Ele compartilhou com seu antepassado remoto do século treze a "autoconsciência e premeditação (que) em geral acredita-se sejam prejudiciais para as metas espirituais" (Braudy, 1997:223). Tal atitude não contradiz a aspiração dos

${ }^{17} \mathrm{O}$ simbólico corresponde à forma convencional de reagir perante um perigo dos revolucionários na época. 
dois "profissionais na auto-definição": São Francisco e o Che tentaram alcançar a perfeição em suas vidas de homens públicos virando a imagem daquilo que eles mais desejavam para suas comunidades. Para Francisco foi o exemplo da vida de Cristo; as aventuras literárias para o jovem Ernesto, quem as achou "em Jules Verne, Alexandre Dumas, Emilio Salgari, Robert Louis Stevenson e Miguel de Cervantes". ${ }^{18}$ Tais foram os ícones que ajudaram às duas celebridades a conformar suas vidas, e a inspirar as de incontáveis pessoas. Apesar do Che ter negado a imagem de Cristo como ícone de sua vida, no fragmento da carta colocada na epígrafe, essa imagem representa o destino aonde seus passos o conduziram, quando se transformou em um célebre christomimétés do século XX.

Para ambos São Francisco e o Che, a negação do self, das tentações da vida confortável em que nasceram, envolveu virar indivíduos extraordinários, atrativos para outros pelas suas qualidades. Nisso consiste o paradoxo da celebridade icônica. Braudy (1997: 224) afirma que "em certo sentido Francisco era as Cruzadas trazidas a casa," tão grande era o impacto de sua "fama do espírito" em seu auditório. Analogamente, o jovem argentino também "foi possuído por uma sede de martírio" (id.) e rejeitou os confortos terrenos, para que as pessoas em redor dele o seguissem para a nova ordem do mundo que a revolução socialista iria criar. Para essa meta, como seu precursor medieval, o Che necessitou "ser uma testemunha da verdade de Deus, mas uma testemunha que ela própria também fosse testemunhada, um exemplo para outros" (id). Alcança substituir 'Homem Novo Socialista' por "Deus" na cita, e o paralelismo entre os dois personagens se torna evidente. Como é possível virar um exemplo sem se tornar exemplar ao mesmo tempo? Tal o maior dilema da celebridade icônica que é o Che Guevara.

\section{CONSIDERAÇÕES FINAIS: O ENIGMA DE UM SIGNO EVANESCENTE}

Se, conforme afirma Rose (1998), o enigma da celebridade se resume em que o fenômeno "ao mesmo tempo evoca e aniquila o mistério",

${ }^{18}$ A informação provém do primeiro capítulo da biografia de Taibo Também conhecido como o Che, na sua tradução inglesa, no website de The Washington Post (http://www.washingtonpost.com/). 
o ícone enquanto qualidade absoluta é o signo que melhor dá conta do enigma. Ambos os personagens são símbolos globais, Evita e Che, capazes de gerar um efeito predominantemente icônico em aqueles que veneram sua memória, que possuem e contemplam alguma imagem concreta deles, quer um pôster, quer uma fotografia, quer uma tatuagem. Tais ícones representam as vidas e as ações gloriosas de signos icônicos globalizados e nascidos na Argentina. A pergunta central do presente trabalho é: que faz uma pessoa virar uma celebridade icônica além das fronteiras e das condições sócio-históricas restritas do nascimento e da atividade concreta realizada? Qualquer que seja a resposta, essa deveria incluir as seguintes considerações:

a) A teoria do signo icônico (Peirce). $\mathrm{O}$ ícone se assemelha a um sonho e nos permite contemplar a realidade através da exibição de alguma qualidade própria, e não somente compreendê-la, que é a função do símbolo.

b) A reflexão sobre a natureza dual do rei medieval (Kantorowicz). A reunião do corpo natural e do corpo político fazia do soberano um christomimétés: um signo icônico de Cristo, uma figura quase divina, mas não por natureza e sim pela graça. Para adotar essa noção histórica à nossa época midiática proponho o conceito de corpo icônico pela tecnologia midiática da imagem.

c) A análise da obra de arte enquanto signo auto-representativo (Ransdell). O efeito semiótico é produzir em seu intérprete a experiência de "uma presença subjugante". O signo icônicoestético oferece um acesso perceptivo realçado a seu objeto.

Em resumo, caraterizo o tipo particular de celebridade alcançada pelos dos personagens históricos como um processo análogo ao que converte um objeto qualquer em uma obra de arte. É na contemplação de alguma qualidade inseparável de sua imagem pública que reside o efeito de celebridade icônica. Transcendentes de suas áreas de ação objetiva, Evita e Che viraram signos icônicos modernos de um poderoso sonho coletivo que parece crescer ao longo do tempo. O fascínio icônico deve pouco aos índices - aqueles fatos reais ou realizações concretas de suas vidas - e 
aos símbolos - o significado conceptual de suas ações, p. ex., a ideologia defendida por eles.

A noção de ícone como qualidade absoluta contribui a explicar o mistério de uma figura pública que, estando tão presente ao olhar público e à mirada interna da imaginação coletiva, consegue sempre nos evadir. Em uma espécie de ato prodigioso de Houdini, cada vez que tentamos capturar a real natureza de uma celebridade icônica como Evita ou Che, nosso objeto some do palco. Esse curioso funcionamento semiótico corresponde ao efeito de sentido que produzem as qualidades absolutas, p. ex., a qualidade cristo-icônica. A fenomenologia da experiência peirceana descreve o ícone como uma qualidade ou sentimento puro (feeling), que não faz referência mais que a si próprio: "Apenas uma possibilidade é um ícone em virtude de sua qualidade" (CP 2.276). Dessa qualidade estão feitos nossos sonhos e aqueles poucos seres humanos que os povoam com suas sempre renovadas sugestões de liberdade, de "uma variedade e multiplicidade não controladas" (CP 1.302).

\section{REFERÊNCIAS}

ANDACHT, Fernando. "Big brother te está mirando: la irresistible atracción de un reality show global”. In: Ética, cidadania e imprensa. Raquel PAIVA (org.). São Paulo: Mauad, 2002. p. 63-100.

. "Those powerful materialized dreams: Peirce on icons and the human imagination". American Journal of Semiotics. Vol. 17, 3: p. 14972. 2002a.

. "El reality show". Buenos Aires: Grupo Norma, 2003.

. "Fight, love and tears: an analysis of the reception of Big Brother in Latin America”. Ernest MATHIJS \& Janet JONES (Orgs.). Big Brother International. Formats, critics \& Publics. London: Wallflower Press, p. 123-139, 2004.

BRAUDY, Leo. "The frenzy of renown: Fame and its history". New York: Vintage Books, 1997. 
COLAPIETRO, Vincent. "Dreams: such stuff as meanings are made on". Versus No. 49: p. 65-79. 1988.

DUJOVNE ORTIZ, Alicia. "Eva Perón: La biografía." Madrid: Aguilar, 1995.

GARCÍA LUPO, Rogelio "Ernesto Che Guevara”. In Clarín Los 10 Argentinos del Siglo XX. Buenos Aires, 2000.

GOFFMANN, Erving. "The presentation of self in everyday life”. New York: Doubleday Anchor, 1959.

. “Gender Advertisements”. London: Macmillan, 1985.

. "Frame analysis: an essay on the organization of experience".

Boston: Northeastern University Press, 1986.

GUEVARA, Ernesto Back. "On The Road: a journey to Central America”. Tradução de Patrick Camiller, 2001. London: Harvill Press. Retirado de The Guardian http://books.guardian. co.uk) em 11 set. 2001.

KANTOROWICZ, Ernst. "The king's two bodies: a study in mediaeval political theology”. Princeton: Princeton University Press, 1957.

KING, Barry. "Stardom and symbolic degeneracy: television and the transformation of the stars as public symbols". Semiotica. $92-1 / 2$, p. 1- 47, 1992.

KORDA, Alberto. “The man who made an icon”. Retirado de http:// www.netssa. com/che.html, em 10/03/2001.

MARTÍNEZ, Tomás. "Santa Evita”. Buenos Aires: Planeta, 1995.

MEYROWITZ, Joshua. "No sense of place: the impact of electronic media on social behavior”. New York: Oxford University Press, 1986.

PEIRCE, Charles. "Collected Papers of C. S. Peirce, C. Hartshorne, P. Weiss and A. Burks (Orgs.)”. Cambridge, Mass.: Harvard University Press, 1931-58.

RAMONET, Ignacio. "Construcción de celebridades descartables". Le Monde diplomatique, No. 24: 36-40, 2001. 
RANSDELL, Joseph. "On Peirce's conception of the iconic sign". In POSNER, Roland (org.) et al. "Iconicity: Essays on the nature of culture". . Tübingen: Stauffenburg Verlag, 1996.

. "The semiotical conception of the Artwork". In: "First Advanced Seminar in Peirce's Philosophy And Semiotics”, São Paulo: Centros de Estudos Peirceanos, PUC/SP, 2002.

ROSE, Jacqueline. “On celebrity: London Review of Books”. Retirado de: http://www. lrb.co. uk/v20/n16, em 15 fev. 1998.

SINAY, Sergio; SCENNA, Miguel Angel. Che Guevara para principiantes. Buenos Aires: Era Naciente, 1996.

TAIBO, Paco. "Capítulo 1" de Guevara, Also Known As Che. Tradução de M. M. Roberts, London: St. Martin's. Retirado de The Washington Post, http://www.washingtonpost.com/, em 15 ago. 1998. 